A N N A L E S

UNIVERSITATIS MARIAE CURIE-SKŁODOWSKA LUBLIN - POLONIA

VOL. XXIX, 3

SECTIO J

2016

Krakowska Akademia im. Andrzeja Frycza Modrzewskiego.

Wydział Psychologii i Nauk Humanistycznych

\title{
JOANNA AKSMAN
}

joannaaks@interia.pl

\section{Kształcenie i dokształcanie nauczycieli edukacji wczesnoszkolnej $w$ aspekcie pracy z dziećmi zdolnymi plastycznie}

Educating and training teachers of young learners to work

with artistically gifted children

\section{STRESZCZENIE}

Artykuł przedstawia opis projektu „Nauka - Sztuka - Edukacja” realizowanego w Krakowskiej Akademii im. Andrzeja Frycza Modrzewskiego w latach 2011-2013. Jego istotą było stworzenie nowej sieci współpracy w dziedzinie edukacji dzieci zdolnych plastycznie z klas I-III szkoły podstawowej na bazie doświadczeń podmiotów zagranicznych: ze Słowacji, Słowenii, z Ukrainy i Polski. Autorka przedstawia wybraną strategię kształcenia i dokształcania nauczycieli edukacji wczesnoszkolnej. Ukazuje szereg postulatów, których spełnienie może prowadzić do poprawy procesu kształcenia nauczycieli zarówno na szczeblu ministerialnym, jak i w praktyce szkolnej i we współdziałaniu uczelni oraz nauczycieli. W końcowej części artykułu autorka opisuje aktualną fazę realizacji trzyletniego programu wdrażania modelu NSE w wybranych szkołach Małopolski.

Słowa kluczowe: kształcenie i dokształcanie nauczycieli; edukacja plastyczna w młodszym wieku szkolnym; model pracy z dziećmi zdolnymi plastycznie; „Nauka - Sztuka - Edukacja”

\section{WPROWADZENIE}

Projekt „Nauka - Sztuka - Edukacja”' realizowany w latach 2011-2013 w Krakowskiej Akademii im. Andrzeja Frycza Modrzewskiego zakładał stworzenie nowej sieci współpracy w dziedzinie edukacji dzieci zdolnych plastycznie

\footnotetext{
${ }^{1}$ Opis Modelu NSE pochodzi z opublikowanego wcześniej artykułu autorki (Aksman 2015, s. 107-121).
} 
z klas I-III szkoły podstawowej z podmiotami zagranicznymi, takimi jak: Univerza na Primorskem (Słowenia), Uniwersytet Katolicki w Ružomberku (Słowacja) i Liceum przy Donieckim Uniwersytecie Narodowym (Ukraina) oraz Polskie Stowarzyszenie Wychowania Pozaszkolnego im. Aleksandra Kamińskiego. Głównym założeniem tej współpracy było opracowanie Innowacyjnego modelu diagnozy, metod, form pracy $i$ opieki nad uczniem uzdolnionym plastycznie przeznaczonego dla nauczycieli klas I-III oraz studentów i wykładowców uczelni wyższych na kierunkach pedagogicznych.

Wiele państw opracowuje zmiany prawne w celu zwiększenia ofert edukacyjnych dla uczniów zdolnych. Efekty tych działań dopiero zostaną poddane ewaluacji. Stworzony w projekcie model wpisuje się zatem w innowacyjne działania edukacyjne podejmowane obecnie w całej Unii Europejskiej.

Edukacja artystyczna - w tym edukacja w zakresie sztuk plastycznych, tak ważna w rozwoju dziecka - została przesunięta na mało znaczące miejsce jako przedmiot, na którego realizację przeznacza się niewiele czasu w strukturze kształcenia ogólnego. Taka sytuacja spotykana jest nie tylko w województwie małopolskim, ale również na obszarze całego kraju. Tendencja do zmniejszania liczby godzin przeznaczonych na edukację plastyczną spowodowała gwałtowne obniżenie poziomu kształcenia, a także zmniejszenia kompetencji i umiejętności uczniów w zakresie sztuk plastycznych. Pojawiła się również praktyka prowadzenia zajęć z przedmiotu plastyka przez osoby nieposiadające żadnego wykształcenia w tym kierunku.

Twórczość plastyczna jest podstawową formą ekspresji, wyrazem indywidualnego rozwoju psychicznego dzieci, środkiem służącym rozwojowi procesów poznawczych i emocjonalnych oraz uczuć wyższych. Najważniejsze jest zainteresowanie dziecka sztuką, stworzenie mu warunków do wykorzystania swoich umiejętności i zachęcanie do twórczego spędzania czasu. Dlatego tak istotną rolę w szkołach oraz placówkach wychowania pozaszkolnego pełnią nauczyciele.

\section{OPIS PROJEKTU „NAUKA - SZTUKA - EDUKACJA”}

Tytuł projektu „Nauka - Sztuka - Edukacja, opracowanie i upowszechnianie Innowacyjnego modelu diagnozy, metod, form pracy i opieki nad uczniem zdolnym plastycznie" wskazuje na wagę nauki w edukacji przez sztukę w klasach I-III. Sygnalizuje, że ważne jest nie tylko opieranie się na kreatywności dziecka prezentowanej w sposób dowolny (często nadużywane przez nauczycieli), ale na wykorzystaniu nauki w sztuce. Współcześnie sztuka staje się dziedziną interdyscyplinarną: sięga do technologii informacyjnej, pojawia się w życiu publicznym podczas konferencji, wystąpień publicznych czy spotkań prywatnych. W związku z tym w projekcie podkreślone zostały waga i rola źródeł naukowych w edukacji dzieci przez sztukę i połączenia ich z innymi dziedzinami wiodącymi prym 
w rozwijającym się społeczeństwie, np. technologią informacyjną. W przyszłości tak pojęte zadania projektu mają się przyczynić do zwiększania świadomości własnych działań twórczych i kreatywnych wynikającej z wiedzy na temat głównych założeń naukowych oraz do możliwości zatrudnienia osób zdolnych plastycznie w różnych zawodach.

Autorami modelu są naukowcy i praktycy na co dzień pracujący z dziećmi w wieku przedszkolnym oraz wczesnoszkolnym, pedagodzy, psycholodzy, historycy sztuki, metodycy edukacji plastycznej. Interdyscyplinarne zespoły opisały poszczególne elementy modeli pracy z dzieckiem zdolnym plastycznie w krajach partnerskich oraz - na podstawie badań porównawczych - biorąc pod uwagę wnioski wyciągnięte z opisów pracy z dzieckiem zdolnym plastycznie w krajach partnerskich, opracować model końcowy możliwy do wdrożenia w warunkach pracy polskiej szkoły. Poszczególne elementy modelu to:

1. Część diagnostyczna (opisująca specyfikę procesu diagnostycznego dziecka zdolnego oraz zawierająca wybrane i przetłumaczone na język polski narzędzia diagnostyczne stosowane do diagnozy dzieci zdolnych w krajach partnerskich).

2. Część psychologiczno-pedagogiczna (obejmująca obszary i sposoby wsparcia dziecka zdolnego plastycznie).

3. Część programowa (dotycząca programów edukacji plastycznej).

4. Część poświęcona kształceniu nauczycieli edukacji plastycznej.

5. Część metodyczna (ukazująca formy i metody pracy z dzieckiem zdolnym plastycznie).

Elementy modeli pracy z dziećmi zdolnymi plastycznie w krajach partnerskich (Słowacji, Słowenii, Ukrainie) oraz model skomponowany na podstawie zgromadzonych materiałów, możliwy do adaptacji w warunkach pracy polskiej szkoły, został szczegółowo opisany w pierwszej i drugiej części publikacji: $\mathrm{Na}$ $u k a-S z t u k a-E d u k a c j a$. Innowacyjny model diagnozy, metod, form pracyi opieki nad uczniem zdolnym plastycznie (Aksman 2013). W części trzeciej zamieszczono wybrane na potrzeby modelu narzędzia diagnozy dziecka zdolnego plastycznie wykorzystywane na Ukrainie i w Słowenii oraz materiały pomocnicze dla nauczycieli: przykładowy scenariusz zajęć opracowany przez Danutę Skulicz, ukazujący innowacyjność w prowadzeniu zajęć plastycznych według teorii kształtowania umiejętności życiowych młodego człowieka, kategorie analizy dzieła plastycznego według Stanisława Popka, prace plastyczne dzieci ze Słowacji, Słowenii i Ukrainy oraz filmy obrazujące dobre praktyki wdrażania modelu NSE w szkołach zagranicznych i małopolskich.

Model wprowadzono w wybranych placówkach na terenie Małopolski w semestrze letnim roku szkolnego 2012/2013. Od roku akademickiego 2013/2014 włączony jest także do programu kształcenia przyszłych nauczycieli na kierunku pedagogika, specjalności pedagogika wczesnoszkolna w Krakowskiej Akademii 
im. Andrzeja Frycza Modrzewskiego i być może w innych uczelniach. Publikacja została bowiem wysłana do małopolskich placówek kształcących nauczycieli edukacji wczesnoszkolnej.

W projekcie uczestniczyło łącznie około 260 osób. Brały one udział w działaniach z zakresu współpracy międzyregionalnej.

W założeniach projektu zawarto szereg celów szczegółowych/bezpośrednich, m.in.:

- podniesienie kwalifikacji nauczycieli i studentów kierunku pedagogika wczesnoszkolna Krakowskiej Akademii im. Andrzeja Frycza Modrzewskiego z zakresu diagnozy, pracy i opieki nad dziećmi uzdolnionymi plastycznie dzięki wyjazdom edukacyjnym do krajów partnerskich,

- kształtowanie postaw kreatywnych u nauczycieli oraz przyszłych nauczycieli (studentów) przez obserwację wzorców zagranicznych podczas wyjazdów edukacyjnych,

- stworzenie Innowacyjnego modelu diagnozy, metod, form pracy i opieki nad uczniem zdolnym plastycznie z wykorzystaniem modeli wypracowanych w krajach partnerskich,

- uatrakcyjnienie programu studiów kierunku pedagogika przez wprowadzenie przedmiotu dotyczącego Innowacyjnego modelu diagnozy, metod, form pracy i opieki nad uczniem zdolnym plastycznie,

- transfer wiedzy, dobrych praktyk dotyczących pracy z uczniem zdolnym plastycznie dzięki utworzeniu nowych sieci współpracy.

Ostatni z celów szczegółowych - najistotniejszy ze względu na perspektywy związane z wdrażaniem modelu - dotyczył rozpoczęcia transferu wiedzy oraz dobrych praktyk w pracy z uczniem zdolnym plastycznie możliwych dzięki utworzeniu nowych sieci współpracy. W tym celu uruchomiona została międzynarodowa strona internetowa (www.artisticallygifted.eu), na której sukcesywnie zamieszczano opisy poszczególnych działań w projekcie oraz materiały uczestników projektu - zarówno zagranicznych, jak i polskich. Są to: prezentacje multimedialne, teksty naukowe, fragmenty badań studenckich dotyczących dziecka zdolnego plastycznie, relacje filmowe i fotograficzne (filmy i biuletyny projektowe). Na stronie internetowej projektu znajduje się także publikacja opisująca model NSE wraz z uwagami na temat jego wdrażania, materiałami dla nauczycieli i wykładowców oraz narzędziami diagnostycznymi i filmami (filmem podsumowującym informacje związane z modelem i sposobem jego wdrażania, który został przetłumaczony na trzy języki: słowacki, słoweński i ukraiński).

Do widocznych rezultatów projektu zaliczyć można także:

- nową sieć współpracy,

- publikację zawierającą teoretyczną podbudowę oraz opis Innowacyjnego modelu diagnozy, metod, form pracy i opieki nad dzieckiem zdolnym plastycznie, 
- trzy filmy obrazujące modele pracy z dzieckiem zdolnym plastycznie w edukacji wczesnoszkolnej na Słowacji, Ukrainie i w Słowenii,

- narzędzia do badań diagnostycznych i ewaluacji Innowacyjnego modelu diagnozy, metod, form pracy i opieki nad uczniem zdolnym plastycznie (narzędzia diagnostyczne i materiały pomocnicze znajdują się w trzeciej części publikacji opisującej model „Nauka - Sztuka - Edukacja”),

- recenzje specjalistów z krajów partnerskich dotyczące Innowacyjnego modelu diagnozy, metod, form pracy i opieki nad uczniem zdolnym plastycznie (fragmenty przedstawione zostały $\mathrm{w}$ jednym $\mathrm{z}$ podrozdziałów trzeciej części raportu z badań nad wdrażaniem modelu),

- raport z wnioskami końcowymi i rekomendacjami,

- biuletyn dotyczący sieci współpracy (cztery numery są dostępne na stronie internetowej projektu zakładce: Aktualności).

Wypracowany model opiera się na:

- teorii twórczości rysunkowej dzieci Stefana Szumana,

- psychologicznej koncepcji rozwoju twórczości plastycznej dzieci Stanisława Popka,

- koncepcji Petera Aggletona dotyczącej struktury oraz kształtowania umiejętności życiowych, które umożliwiają człowiekowi pozytywne zachowania przystosowawcze, a przez to także skuteczne radzenie sobie z zadaniami (wymaganiami) i wyzwaniami codziennego życia (termin „umiejętności życiowe” odnosi się do umiejętności psychospołecznych, osobistych, społecznych, interpersonalnych, poznawczych, afektywnych, uniwersalnych),

- modelu struktury zdolności plastycznych według Stanisława Popka i Wiesławy Limont,

- ogólnej teorii zdolności: Trójpierścieniowym Modelu Zdolności Josepha Renzulliego (zob. Aksman 2013).

Poszczególne elementy opisujące model to: cele, normy, części modelu, zasady wprowadzania, wartości modelu, przełamywanie stereotypów, wiedza, zastosowanie w systemie oświaty, kryteria naboru, diagnoza, metody działania, kryteria rozwoju modelu.

\section{KONCEPCJA KSZTAŁCENIA NAUCZYCIELI W MODELU „NAUKA - SZTUKA - EDUKACJA”}

Niezbędnym warunkiem wdrożenia jakichkolwiek zmian w edukacji szkolnej jest odpowiednie przygotowanie kadry nauczycielskiej. Dlatego już po zakończeniu realizacji projektu w Krakowskiej Akademii im. Andrzeja Frycza Modrzewskiego odbywa się szereg szkoleń przeznaczonych dla nauczycieli edukacji wczesnoszkolnej, wychowawców w świetlicach szkolnych i ośrodkach pozaszkolnych. Nauczyciele coraz częściej odczuwają potrzebę wykorzystywa- 
nia edukacji plastycznej w nauczaniu dzieci w młodszym wieku szkolnym jako antidotum na najczęstszą formę spędzania przez nie czasu wolnego - obcowanie $\mathrm{z}$ mediami elektronicznymi.

$\mathrm{Z}$ modelem należy zapoznawać nie tylko doświadczonych już nauczycieli, ale także studentów, przyszłych absolwentów specjalności nauczycielskich. Aby było to możliwe, na podstawie doświadczeń zgromadzonych podczas wizyt na Słowacji, w Słowenii i na Ukrainie skomponowany został model kształcenia współczesnych nauczycieli edukacji wczesnoszkolnej, uwzględniający w szczególności metody pracy z dziećmi zdolnymi. Zasadza się on na jednym z modeli kształcenia nauczycieli, stworzonym na gruncie polskim modelu refleksyjnego praktyka (Aksman 2013b, s. 301). Warto przypomnieć, że Ewa Żmijewska (Żmijewska 1995, s. 399-401) przedstawiła kilka takich modeli, których autorami są m.in.: Henryka Kwiatkowska, Henryka Mizerek, Joanna Rutkowiak, Wojciech Muzyk i Henryk Mizerek, Kazimierz Denek, Wincenty Okoń, Tadeusz Lewowicki i Krystyna Duraj-Nowakowa. Żmijewska wprowadziła ogólny podział na:

1. Strategie o charakterze akademickim (prymat teorii).

2. Strategie kładące nacisk na rozwój osobowości nauczyciela (odkrywanie własnej indywidualności).

3. Strategie czerpiące z psychologii behawioralnej (jednostronny indywidualizm).

4. Strategie oparte na fundamentach psychologii poznawczej (nauczyciel samodzielny podmiot, badacz rzeczywistości).

5. Strategie przygotowujące do rozwiązywania problemów (nacisk na rozwijanie umiejętności krytycznej refleksji i osiągania celów ważnych dla podmiotu).

Duża refleksyjność nauczycieli, zwłaszcza pracujących z uczniami zdolnymi, nie wystarcza. Dlatego do opisu budowanego przez nas obrazu przyszłego nauczyciela pomocna staje się także koncepcja mocnego profesjonalizmu (Giza 2013, s. 347), w której liczą się krytyczny namysł nad praktyką oraz doświadczenie badawcze, a także umiejętność kontaktu z drugim człowiekiem.

Zatem kształcenie nauczycieli przygotowanych także do pracy z uczniami zdolnymi należałoby prowadzić zgodnie z założeniami strategii refleksyjnego praktyka i nauczyciela-profesjonalisty. Trudno jednak wybrać i realizować kształcenie nauczycieli jedną li tylko drogą modelową. Teresa Olearczyk za Stanisławem Dylakiem zwraca uwagę na konieczność modyfikacji kształcenia nauczycieli: „W całym procesie kształcenia dokonywać się powinny zmiany, które będą zgodne z oczekiwaniami, stawianymi nauczycielom przez społeczeństwo i zmiany kulturowe" (Olearczyk 2013, s. 72).

Wziąwszy pod uwagę powyższe oraz zbudowany w toku trwania projektu model pracy z dzieckiem zdolnym plastycznie, zebrano doświadczenia zawodowe nauczycieli akademickich i nauczycieli dzieci w młodszym wieku szkolnym 
w krajach uczestniczących w projekcie (Słowacji, Słowenii i Ukrainie) i sformułowano postulaty dotyczące pracy zarówno Ministerstwa Edukacji Narodowej, jak i samych nauczycieli oraz współdziałania uczelni i nauczycieli czynnych zawodowo.

\section{POSTULATY DOTYCZĄCE PRACY MINISTERSTWA EDUKACJI NARODOWEJ, WSPÓŁDZIAŁANIA UCZELNI I NAUCZYCIELI ORAZ PRACY SAMYCH NAUCZYCIELI W ASPEKCIE KSZTAŁCENIA I DOKSZTAECANIA NAUCZYCIELI EDUKACJI WCZESNOSZKOLNEJ}

Postulaty dla Ministerstwa Edukacji Narodowej wynikające z dobrych praktyk Słowacji, Słowenii i Ukrainy przedstawiają się następująco:

1. W modelu polskim należy przyjąć - tak jak w Słowenii - jednolitą formę diagnozy dzieci zdolnych. Zastosowanie testu OLNAD07 w warunkach polskich wymagałoby jednak standaryzacji.

2. Warto wykorzystać pomysł umieszczania wszystkich opiniowanych przez zespół ekspertów i godnych polecenia kursów na stronie Ministerstwa Edukacji. Godne powielenia są także warunki uczestnictwa w kursie, a zwłaszcza działania wymagane przez organizatorów (sporządzanie raportu i opisu formy wykorzystania wiedzy z kursu w codziennych zadaniach edukacyjnych).

3. Trzeba zmienić wymogi zawarte w podstawach programowych. Nauczyciele powinni mieć zagwarantowaną dowolność w wyborze z puli tematów opracowanych przez Ministerstwo Edukacji Narodowej takich, które ich zdaniem są najbardziej odpowiednie dla uczniów.

4. Konieczne wydaje się nabycie przez nauczycieli umiejętności pedagogicznych związanych z nauczanymi przedmiotami artystycznymi. Na Ukrainie przedmiotów tych (muzyki, plastyki) już od I klasy szkoły podstawowej uczą profesjonaliści, co świadczy o rzetelnym podejściu do tej dziedziny już od początku edukacji szkolnej. Program studiów dla nauczycieli edukacji wczesnoszkolnej poszerzany jest o przedmioty prowadzone nie tylko przez pedagogów, metodyków plastyki, ale także przez artystów. Jeśli chodzi o Europę, podobnie jest tylko w Danii, na Łotwie i w Niemczech.

W postulatach sformułowanych dla uczelni, które prowadzą kształcenie nauczycieli edukacji wczesnoszkolnej, zawarto następujące punkty:

1. Wprowadzenie nowych przedmiotów i form kształcenia:

- ,praca z dzieckiem zdolnym”,

\footnotetext{
${ }^{2}$ „W Uniwersytecie Katolickim w Rużomberku na kierunku: pedagogika nie ma osobnego przedmiotu poświęconego tej tematyce, ale widzi się podobnie jak w Polsce potrzebę wprowadzenia wiedzy o dziecku zdolnym (przede wszystkim diagnozy i metod oraz form pracy z dzieckiem zdolnym) jako treści osobnego i obowiązkowego przedmiotu - poczyniło tak już kilka słowackich uniwersytetów" (Muchacka 2013)
} 
- „historia regionu i dziedzictwo kulturowe” (Muchacka 2013)3.

2. Kształcenie nauczycieli mogących podjąć się prowadzenia innych niż lekcyjne form pracy z uzdolnionymi dziećmi:

- prowadzenie lekcji muzealnych i kół zainteresowań,

- organizowanie zajęć w publicznych szkołach popołudniowych, gdzie za niewielką opłatą (kwota jest zbliżona do tej, którą polscy rodzice przeznaczają na materiały potrzebne w kółkach zainteresowań) dwa razy w tygodniu odbywają się zajęcia z dziedziny sztuki, a na zakończenie uczestnicy otrzymują dyplomy.

3. Kształcenie nauczycieli mogących pracować w „uniwersytetach dla dzieci” lub współpracować z takimi placówkami (Muchacka 2013, s. 96), nauczanie metod diagnozowania uzdolnień i wskazywania rodzicom możliwości dalszego rozwoju dziecka ${ }^{4}$.

4. Kształcenie nauczycieli mogących podjąć pracę w szkołach dla dzieci uzdolnionych ${ }^{5}$.

5. Umieszczenie w programach kształcenia nauczycieli edukacji wczesnoszkolnej co najmniej dwóch przedmiotów (metodycznego i merytorycznego) poszerzających wiedzę z danej dziedziny artystycznej:

- „metodyki wychowania plastycznego” w przedszkolu i klasach I-III,

- „osobistego rozwoju umiejętności artystycznych” (lub innego przedmiotu prowadzonego przez artystę).

6. Wprowadzenie przedmiotu ,praca z dzieckiem zdolnym” już na pierwszym etapie nauczania (połączone z przygotowaniem polskiego nauczyciela do pracy z takim dzieckiem od wczesnej edukacji oraz jednolitą formą diagnozy i nauką pisania programów indywidualnej pracy), a na drugim - poszerzanie wiedzy o dodatkowe metody i przykłady pracy z uzdolnionymi i utalentowanymi dzięki przedmiotowi „,metody pracy z dziećmi uzdolnionymi i utalentowanymi”.

${ }^{3} \mathrm{Na}$ Słowacji dużą rolę przypisuje się kształceniu nauczycieli przez zapoznawanie ze sztuką mikroregionu, a zwłaszcza sztuką ludową, którą Słowacy się szczycą i, korzystając z programów unijnych (grantowych), odnawiają ją oraz upowszechniają. Jest to jeden z głównych przedmiotów kształcenia nauczycieli w dziedzinie sztuki i kultury (obok takich przedmiotów szczegółowych, jak: lalkarstwo, garncarstwo, rzeźba i in.).

${ }^{4}$ Uniwersytety dla dzieci w Polsce działają od 2007 roku i powstały jako forma atrakcyjnych spotkań dzieci (6-13 lat) z naukowcami na terenie uczelni wyższych. W Polsce taką działalność prowadzi już coraz więcej ośrodków naukowych, np.: Uniwersytet Jagielloński, Uniwersytet Warszawski, Uniwersytet Wrocławski, Uniwersytet Warmińsko-Mazurski.

${ }^{5}$ Pomysłem godnym polecenia i dalszego realizowania w polskim procesie kształcenia nauczycieli jest współpraca uczelni z tzw. szkołami ćwiczeń, która powinna uwzględniać organizowanie spotkań nauczycieli i nauczycieli akademickich, metodyków i studentów, jak również poszerzanie wiedzy pracujących już pedagogów o najnowsze doniesienia badawcze i diagnostyczne dotyczące pracy z dzieckiem zdolnym w edukacji wczesnoszkolnej. 
7. Przypisanie większego znaczenia praktykom na drugim stopniu studiów nauczycielskich, zwłaszcza o profilu praktycznym.

8. Wprowadzenie różnych spotkań na zewnątrz i wewnątrz uczelni jako formy motywowania studentów ${ }^{6}$.

9. Organizowanie niestandardowych, ciekawych i potrzebnych akcji, np.: podróżujący autobus ekspercki (z doradcami zajmującymi się różnorodną problematyką, podróżującymi po wielu szkołach, chętnymi do rozmowy, szkolenia i doradztwa, dzielenia się wiedzą i doświadczeniem zawodowym - to bardzo ciekawy pomysł na projekt diagnostyczno-badawczy).

10. Przygotowanie studentów do współpracy z muzeami, gdzie - podobnie jak w Polsce - odbywają się lekcje muzealne.

Do dobrych praktyk godnych naśladowania przez uczelnie (przy współudziale nauczycieli) można zaliczyć:

1. Niezależne pedagogiczne wykłady i warsztaty?

2. Wspólne badania studentów i naukowców nad zagadnieniem dziecka zdolnego we wczesnym dzieciństwie.

3. Wsparcie adaptacji zawodowej młodych nauczycieli przez wprowadzenie dorocznych spotkań z absolwentami uczelni w ramach „Szkoły młodego nauczyciela” (proponowana nazwa: „Szkoła ex professo”).

4. Wprowadzenie mechanizmów motywowania nauczycieli (wybór Nauczyciela Roku oraz przyznawanie innych tytułów nauczycielskich - lokalnych i państwowych).

5. Zwiększenie liczby nauczycieli i studentów wspólnie podejmujących prace eksperymentalne i wprowadzających innowacje podczas praktyk studenckich.

6. Przygotowywanie nauczycieli do zajęć na półkoloniach, koloniach i plenerach artystycznych prowadzonych zarówno przez psychologów rozwijających kreatywność, twórczość młodych ludzi oraz nauczycieli szkół współpracujących z uczelniami, jak i przez twórców sztuki .

${ }^{6}$ Permanentne i czasowe wystawy prac studentów i dzieci stanowią ważny element opisywanej formy motywacji. Zdolni studenci powinni mieć szansę na zorganizowanie samodzielnej wystawy własnych prac z oficjalną ceremonią i promocją w mediach zarówno w kraju, jak i w innych miejscach świata.

${ }^{7}$ Nauczyciele zainteresowani wybraną tematyką zgłaszaliby się do dziekana Wydziału Pedagogicznego, a ten kierowałby ich do kierowników katedr w celu uzgodnienia programów kursów i warsztatów, na jakie uczęszczaliby wraz ze studentami. Programy dokształcania byłyby więc indywidualne, zgodne z potrzebami nauczycieli, nie generowałyby także wysokich kosztów.

${ }^{8}$ Jest to pomysł proponowany do realizacji w Polsce i godny upowszechnienia choćby przez uczelnie kształcące nauczycieli przy wsparciu innych instytucji sztuki, kultury i edukacji. 
Z kolei do działań godnych polecenia polskim nauczycielom należą:

1. Wzajemne motywowanie się do udziału wraz z pracownikami naukowymi w takich formach dokształcania jak projekty i granty badawcze dofinansowywane z Unii Europejskiej oraz do tworzenia ich.

2. Zwrócenie uwagi na działania amatorów, ludzi skupionych wokół różnych zainteresowań lub posiadających dyplomy tych samych nauk, entuzjastów danej dziedziny wiedzy, pracowników naukowych uczelni prowadzących badania oraz współuczestniczących w nich studentów, i włączanie tych osób w proces edukacyjny.

3. Wspólna praca artystyczna nauczycieli i uczniów oraz prezentowanie jej efektów na wystawach (ten sam temat widziany oczami mistrza i ucznia).

4. Zaszczepienie w Polsce bardzo ciekawej inicjatywy polegającej na przedstawianiu treści edukacyjnych - przez nauczycieli, ekspertów niezaangażowanych politycznie, entuzjastów edukacji zainteresowanych rozwiązaniem problemów wychowawczych i dydaktycznych w mediach studenckich (czasopismach, radiu i telewizji uczelnianej) - w postaci możliwych do odtworzenia cyklów (przy współudziale pracowników uczelni).

\section{KONTYNUACJA DZIAŁAŃ W KSZTAŁCENIU I DOKSZTAŁCANIU NAUCZYCIELI EDUKACJI WCZESNOSZKOLNEJ W MODELU NSE}

Nauczyciele szkół, które w roku 2013 brały udział we wdrażaniu modelu, w prowadzonych wywiadach zwrócili uwagę na chęć dalszej współpracy przy pełnej jego realizacji (we wszystkich klasach edukacji wczesnoszkolnej) z możliwością użycia przygotowanych przez specjalistów konspektów zajęć plastycznych oraz słowniczków terminów plastycznych, a także wykorzystanych w tych konspektach technik. Aby wyjść naprzeciw prośbom nauczycieli, do określonego w modelu NSE programu edukacji plastycznej w edukacji wczesnoszkolnej skomponowano zestaw proponowanych tematów oraz konspekty warsztatów plastycznych w postaci publikacji metodycznej z materiałami wizualnymi: pracami artystów, pracami obrazującymi techniki plastyczne, filmem instruktażowym (Aksman, Gabzdyl 2015, s. 1-118). Program odwołuje się do podstaw programowych wychowania przedszkolnego i kształcenia ogólnego w poszczególnych typach szkół z 2012 roku oraz z 2014 roku. Nauczyciele mogą korzystać z proponowanych konspektów w procesie edukacji w wybranym przez siebie czasie, szukając integralności treści konspektów z realizowanym tematem (zgodnym z programem kształcenia). Przedstawione konspekty dla klasy I w chwili obecnej są wdrażane w wybranych szkołach podstawowych Małopolski. W tych samych szkołach pod opieką merytoryczną naukowców prowadzone są badania metodą eksperymentu pedagogicznego, który po trzyletnim wdrażaniu modelu ma ukazać jego efektywność. Celem głównym przedstawionej edukacji plastycznej jest 
dążenie do ukształtowania umiejętności społecznych dziecka w młodszym wieku szkolnym: interpersonalnych, budowania samoświadomości, podejmowania decyzji oraz radzenia sobie ze stresem i kierowania nim, czyli umiejętności zatwierdzonych przez WHO, UNESCO i UNICEF9. Kształtują się one nie tylko przez odpowiednio uporządkowany program kształcenia plastycznego, ale przede wszystkim przez powtarzalność wątków metodycznych użytych w innowacyjnie skomponowanym konspekcie warsztatów plastycznych.

Program jest na początku realizacji, o jego efektach będzie można poinformować za około trzy lata. Jednak rozmowy z nauczycielami podczas spotkań monitorujących przebieg eksperymentu przynoszą wiele pozytywnych emocji. Zarówno nauczyciele, jak i dzieci czekają na zadania warsztatowe z plasty$\mathrm{ki}, \mathrm{z}$ chęcią dzielą się poznanym językiem plastycznym z rodzicami, kolegami i koleżankami z innych klas. Do wykonywania zadań plastycznych, zwłaszcza poza salą lekcyjną, dołączają dzieci z innych klas, powoli w uwagach nauczycieli zauważalny staje się także rozwój umiejętności społecznych dzieci, które biorą udział w projekcie.

\section{ZAKOŃCZENIE}

Prezentowany projekt oraz wynikająca z praktyki szkolnej potrzeba jego wcielenia w życie i sprawdzenia efektów oddziaływania tegoż modelu w rzeczywistości szkolnej napawają optymizmem związanym z możliwością kształtowania pozytywnych wzorców powiązań między teorią a praktyką. Dla naukowców jest to realny obraz realizacji powstałego po trzech latach zbierania informacji i danych międzynarodowych modelu pracy z dzieckiem zdolnym plastycznie w warunkach naturalnych; obraz, który nadaje sens działaniom na polu naukowym. Dla nauczycieli zaś stanowi nie tylko kolejną innowację, ale i sposób działania z uczniem wkraczającym w progi szkoły. Działanie to pobudza kreatywność i wzbogaca wiedzę plastyczną, jak również korzystnie wpływa na rozwój społeczny ucznia. O szczegółach dalszej realizacji modelu w cyklu trzyletnim będzie można jednak poinformować dopiero po określonym czasie.

${ }^{9}$ Propozycja grup umiejętności życiowych i ich rodzajów. Materiały prezentowane w czasie warsztatów zorganizowanych przez WHO i UNICEF (Bratysława, maj 2000, tłum. prof. dr hab. Barbara Woynarowska). 


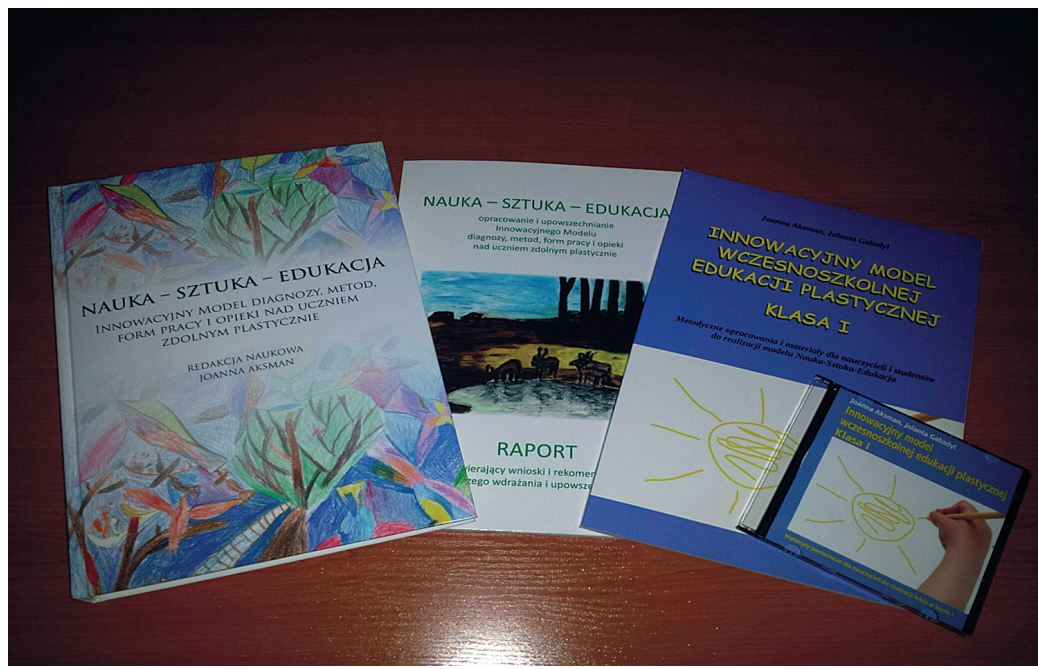

Fotografia 1. Zestaw publikacji obrazujących postępy w pracy nad projektem „Nauka - Sztuka - Edukacja - od teorii do praktyki"

\section{BIBLIOGRAFIA}

Aksman J. (2015), Early childhood education teacher training as conditio of effective implementation of the model of work with gifted children: ,,Teaching - Art-Education”, [w:] J. Kuźma, J. Pułka (red.), The school of Tomorrow Centred on Pupils, Kraków: Oficyna Wydawnicza AFM.

Aksman J. (red.) (2013), Nauka - Sztuka - Edukacja. Innowacyjny model diagnozy, metod, form pracy i opieki nad uczniem zdolnym plastycznie, Kraków: Wydział Psychologii i Nauk Humanistycznych Krakowskiej Akademii im. Andrzeja Frycza Modrzewskiego.

Aksman J. (2013b), Rozwijanie kompetencji nauczycieli w zakresie kształcenia uczniów zdolnych plastycznie - na bazie doświadczeń szkolnictwa Stowacji, Słowenii, Ukrainy i Polski, [w:] J. Aksman (red.), Nauka - Sztuka - Edukacja. Innowacyjny model diagnozy, metod, form pracy i opieki nad uczniem zdolnym plastycznie, Kraków: Wydział Psychologii i Nauk Humanistycznych Krakowskiej Akademii im. Andrzeja Frycza Modrzewskiego.

Aksman J., Gabzdyl J. (2015), Innowacyjny model wczesnoszkolnej edukacji plastycznej. Klasa I. Metodyczne opracowania i materiały dla nauczycieli i studentów do realizacji modelu NaukaSztuka-Edukacja, Kraków: Oficyna Wydawnicza AFM.

Boczarova O., Aksman J. (red.) (2010), Pedagogiczno-społeczne aspekty wsparcie uczniów zdolnych $w$ Polsce i na Ukrainie, Kraków: Oficyna Wydawnicza AFM.

Giza T. (2013), Kształcenie i doskonalenie zawodowe nauczycieli na Ukrainie, [w:] J. Aksman (red.), Nauka - Sztuka - Edukacja. Innowacyjny model diagnozy, metod, form pracy i opieki nad uczniem zdolnym plastycznie, Kraków: Wydział Psychologii i Nauk Humanistycznych Krakowskiej Akademii im. Andrzeja Frycza Modrzewskiego.

Giza T., Pękowska M. (red.) (2012), Być zdolnym - wspierać zdolnych, Kielce: Uniwersytet Jana Kochanowskiego.

Giza T. (2011), Podstawy pracy z uczniem zdolnym, Kielce: Wszechnica Świętokrzyska.

Kuźma J., Pułka J. (red.) (2015), The school of Tomorrow Centred on Pupils, Kraków: Oficyna Wydawnicza AFM. 
Limont W., Cieślikowska J., Jastrzębska D. (2012), Zdolni w szkole, czyli o zagrożeniach i możliwościach rozwojowych uczniów zdolnych. Poradnik dla nauczycieli $i$ wychowawców, Warszawa: Ośrodek Rozwoju Edukacji.

Muchacka B. (2013), Ksztatcenie i doksztatcanie nauczycieli edukacji przedszkolnej i szkolnej w zakresie pracy z dzieckiem zdolnym na Stowacji i w Polsce (porównania i wnioski), [w:] J. Aksman (red.), Nauka - Sztuka - Edukacja. Innowacyjny model diagnozy, metod, form pracy i opieki nad uczniem zdolnym plastycznie, Kraków: Wydział Psychologii i Nauk Humanistycznych Krakowskiej Akademii im. Andrzeja Frycza Modrzewskiego.

Olearczyk T. (2013), Ksztatcenie nauczycieli na Stowacji i w Polsce, [w:] J. Aksman (red.), NaukaSztuka-Edukacja. Innowacyjny model diagnozy, metod, form pracy i opieki nad uczniem zdolnym plastycznie, Kraków: Wydział Psychologii i Nauk Humanistycznych Krakowskiej Akademii im. Andrzeja Frycza Modrzewskiego

Patru E., Kobal L., Education of students and qualification and training of teachers at the faculty of education Koper (FEK), Littoral University (LU), [na:] http://artisticallygifted.eu/materialy/ materialypod [dostęp: 03.06.2017].

Sajdak A., Skulicz D. (red.) (2010), Paradygmaty akademickiego ksztatcenia pedagogów, Kraków: Wydawnictwo UJ.

Skulicz D. (2013), Wsparcie dziecka zdolnego na Stowenii, [w:] J. Aksman (red.), Nauka - SztukaEdukacja. Innowacyjny model diagnozy, metod, form pracy i opieki nad uczniem zdolnym plastycznie, Kraków: Wydział Psychologii i Nauk Humanistycznych Krakowskiej Akademii im. Andrzeja Frycza Modrzewskiego.

Społeczeństwo w drodze do wiedzy. Raport o stanie edukacji 2010 r. (2011), Warszawa: Instytut Badań Edukacyjnych.

Strona internetowa Pedagogicznego Fakultetu Uniwersytetu na Primorskem: www.pef.upr.si [dostęp: 15.01.2016].

Strona internetowa projektu: „Nauka - Sztuka - Edukacja - opracowanie i upowszechnianie Innowacyjnego modelu diagnozy, metod pracy i opieki nad uczniem zdolnym plastycznie": www. artisticallygifted.eu [dostęp: 31.01.2016].

Żmijewska E. (1995), Strategie kształcenia nauczycieli, [w:] J. Kuźma, J. Morbitzer (red.), Edukacja - Szkoła - Nauczyciele. Promowanie rozwoju dziecka, Kraków: Wydawnictwo Naukowe AP.

\section{SUMMARY}

The article presents a description of the project "Science - Art - Education" carried out at Andrzej Frycz Modrzewski Cracow University in the years 2011-2013. The idea of the project - based on the experience from Slovenia, Slovakia, Ukraine and Poland - was to set up a new network of co-operation among teachers of young learners in the area of teaching artistically gifted children in classes 1-3 of primary school. The author presents the selected strategy of teacher education and training based on the created model. She also suggests several ways of improving teacher training and education at ministerial level as well as in everyday school practice and in co-operation between universities and school teachers. In the final part the author describes the current phase of the project realisation in some schools in Małopolska.

Keywords: training of teachers of young learners; artistically gifted children 